\title{
Legal Politic of Gender Responsive Election System (A Concept)
}

\author{
Ristina Yudhanti $^{1 *}$, Adi Sulistiyono ${ }^{1}$, Isharyanto ${ }^{l}$ \\ ${ }^{1}$ Doctoral of Law, Sebelas Maret University, Surakarta, Indonesia
}

\begin{abstract}
The discourse of obligation that female has representatives in politics continuously occurred by the agreement of equal position between male and female. This discourse must be implemented by the state to achieve national purpose as decided by substance and the various instrument by the constitution. By fair and gender equality, so the state is obligated to give protection for implementing gender equality including particular actions involving access, participation, control in development process and equal as well as fair benefit between female and male to gender-based approach. The legal political policy of general election in the future is to fulfill Affirmative Action policy by $30 \%$ quota for woman in the general election system in Indonesia. It has to prioritize several factors which are the change of general election system, the political party, and the political culture approach in Indonesia. It is needed the Political will of a political party as an executor to implement Affirmative Action as well as to realize gender equality in a political position in Indonesia. It is expected that regulation formulating policy of general election and political party in the future is not only focused on normative policy but also balanced by sanction policy.
\end{abstract}

\section{Introduction and Theory Review}

In a democratic state, the highest sovereignty is in conducted by people, then general election is an obligation. General election is a means of turning and replacement of a regime in a state. The notion of election is a screening system for public servants used by many countries in the world using democratic government. For a number of the country, applying or claiming itself as democratic country with people as the sovereignty holder, election is regarded as the main and first symbol or passing grade of the democracy [1]. The implementation of democracy system in Indonesia is contained in the fourth paragraph of The Opening to the 1945 Constitution or Undang- Undang Dasar 1945, stating that the

\footnotetext{
* Corresponding author: ristina_74@yahoo.com
} 
independence of Indonesian nation is formed in "Susunan Negara Republik Indonesia yang berkedaulatan rakyat" dalam suatu "Undang-Undang Dasar Negara Republik Indonesia". The statement is the highlight that democracy is applied together with constitutional state principle [2]. Democracy, in which people are the highest sovereignty holder, means that the whole people can participate to be elected or elect without the consideration of their ethnic, religion, group, and gender. The gender problem in the past time became the main issue particularly in new age government before the reformation era, in which woman in many sectors is few, including in political sector as a strategic policy maker. It must be admitted that reformation era in 1998 gives admission on woman role in social and politic. Several progressive efforts are done to support woman contribution in politic. One of them is done by the amendment of election regulation accommodating woman representatives in the parliament. The characteristic of Election Regulation amendment is by proposing affirmative action issue. The affirmative action issue begins to be popular since the approval of UU No. 10 year 2008 about election of the member of DPR (State Representatives), DPD (regional representative) and DPRD (province and city representatives) and UU No. 2 year 2008 about political party. The interesting material of the both regulations is the "order" concerning the approval of woman representative at least 30 percent of the whole candidates of member of DPR and DPRD. The effort, which has been done by government through affirmative action, is expected that the women representative in public functionary is improved [3].

Discourse about the obligation of a woman having a representative in a politic run in the middle of position similarity guarantee between male and female. The existence of women in parliament gives authority on a woman to make policy contributing the achievement of woman rights in gender similarity. Since the male member is often not able to represent completely female interest due to the difference in interest and patriarchal principle that female interest as well as similarity is not an important discussion. By woman representative in parliament, it will make the female aspiration easy to deliver in the middle of the political dynamic in Indonesia. Although the similar position of citizen in the government and law is not regulated and mandated in UUD 1945 article 27 (verse) 1, the value system referring to man as center has not been lost. The female existence in scopes, in which man is dominant, has not achieved the highest decision maker. Female working in politic faces several limitations, such as, first, ideology and psychological limitation (stereotype, patriarchy, bias gender), second, limitation on human resources (masculine politic, low education, minimum access). Third, institution and structural limitation and financial ability.

\section{Objective of Study}

Electoral law politic in Indonesia in the period of post-reformation realizes gender similarity and electoral law politic in Indonesia in gender perspective in the future.

\section{Methodology}

Research method in this law study is a normative jurisdiction. The normative law study is a study conducted by analyzing reference. The study is conducted is a study about the law principles and systematics by analyzing regulations about the election in the perspective of a politic policy to achieve fairness and similarity of gender. 


\section{Discussion}

The covenant about election is regulated in article 22E UUD 1945. The article covenant is elaborated in the decision of Constitutional Board or Mahkamah Konstitusi (MK) No. 3/PUU-VII/2009.MK stating, the covenant in UUD 1945 gives rules concerning election, includes : a) the election is held periodically once in five years, b) the implementation of election principles are Luber and Jurdil, c) the purpose is to elect the member of DPR, DPD, and DPRD, President and vice President, d) the election participants include political parties and personal, and e) it is about the election holding. The decision of MK also states that other thing, like election system, the election region, the requirementa of the participants, and other is delegated to the regulation maker to determine a legal policy. The legal policy can be formulated along without the negation of people sovereignty principle, similarity, fairness, and non-discrimination contained in UUD 1945 [4].

Legal policy in its meaning of public policy in law aims to improve the citizens' wealth in the whole aspect of life, containing two dimensions interrelated that are a social welfare policy and a social defense policy”. Legal politic as a legal policy and legal product formulated by the authority and applied in a country or in international certainly have such purpose going to be achieved. Thus, each legal politic stated or structured in a legal system has such objectives. There is no legal politic or policy made or formed without an objective.

The future challenge is not far from a legal politic analysis, which the focus of an analysis is ius constitutum to ius constituendum. The ex-chairman of BPHN, TM Radhie defines a legal politic as a statement of state authority objective concerning on law applied in the area and the law development built [5]. The definition involves ius constitutum or law applied in a country currently and ius contituendum or law which must be applied in the future. Opposed to Randhie, Padmo Wahjono said that a legal politic is a basic policy determining direction, form, and content of law to be formulated. The definition is explained more by Padmo Wahjono when he express it in magazine of Forum Keadilan [6] that the legal policy is a policy to hold a state about the criteria to regulate something involving formulation, implementation, and maintenance of the law. The difference in these definitions is not so far. Padmo Wahjono looks the legal politic on the issue of constituendum aspect, and Radhie defines the legal politic as network (interrelated) between ius constitutum and ius constituendum. Based on the definition stated by Padmo Wahjono, analysis about politic behind the release of law is studied in legal politic because it is a political product. The government's commitment to achieve the equivalence and fairness of gender has been stated in UUD 1945 ensuring and protecting human rights without discrimination in race, religion, and gender. Since 1978, the effort to achieve the equivalence and fairness of gender has been stated in GBHN. In the same year, The President formulates Kementrian Muda Urusan Peranan Wanita (MENMUD UPW) or the prospective of Kementrian Pemberdayaan Perempuan dan Perlindungan Anak. In 1984, Indonesia government ratifies "konvensi perempuan", which is the Convention on the Elimination of All Forms of Discrimination Against Women (CEDAW) to be undang-undang No. 7 year 1984.[6] To achieve the fairness and equivalence gender, then it is obligation of the state to protect and guarantee the realization of gender equivalence including specific actions involving access, participation, control in building and taking benefit process, which must be same and fair for woman and man in national development. According to Mahfud MD in "Politik Hukum Pemilu", states that electoral legal politic always changes in time. Legal politic is meant by official line about legal policy, which must be implemented by the state to achieve the state's objectives as determined substance and instrument by the constitution [7]. Law as a tool of social engineering is aimed as a tool to change the community, in this case, law can be used as an agent of change, that is someone or a group of people getting 
trust from community to lead social institution. The leaders change the social system by changing social planned to be in control and monitoring [8].

Referring to the social engineering theory, the discussion's focus is that law is functioned to change social condition in the community to empower woman to achieve gender equivalence. Law in this stage has strategic position through regulation product in controlling change aimed. Briefly, law has own power to create social change in the community, including the influences on community point of view toward woman positioned marginally.

Law and community are as two sides of a coin, in which there is a community there will be law (ibi ius ibi society). They both cannot be separated. There is no society without law and there is no law without society. Law is existed in the community to regulate their lives. It means that it is a law-society relationship. Law is formed by society and implemented by the society. According to Esmi Warasih, law does not move in vacuum and face abstract thing, but it always is certain social order and in living human scope [9]. Its relation to female empowerment in achieving gender equivalence in politics and law is aimed that the legal products can accommodate regulations directing to gender equivalence. It is very important in its functional perspective as social engineering very significantly conducting social change in the society, particularly in the paradigm of gender equivalence in order that a woman in politics and law is able to express her existence. The phenomenon, in the perspective of global politics, shows same tendency around the world. Female in the world of socio-politics feel that they are not represented in legislative and far of the involvement in making decision. Meanwhile, the political arena in each country has special character, but there is a description about them that is the imbalance and unwell condition for woman's participation. Woman entering the political world finds the fact that the environment of politics, culture and social are often bad or act as an enemy. Even at a glance, the composition in making decision in politics in many regions gives evidence that woman faces problems in articulating and determining their interest [10].

In the political history of Indonesia and other developing countries in general, a woman is viewed as slow in her involvement in politics. The stigma that woman is always in domestic position is regarded as thing causing her late to start her carrier in politics [11].

Political parties have dominant roles in the Affirmative Action policy, from recruitment model, cadre of education, and female candidate appointment. Relating to the condition, it needs Political Will from political parties to give similar position for woman in parliament. Regulation of political parties is expected to give tight sanction for parties, which do not posit woman in same political position with man. Beside cultural factor and political parties, effort of the Affirmative action cannot be implemented without good election system. In several amendments of regulation in Indonesia related to the election system, it mandates to allocate quota of $30 \%$ for woman. The formulation of the affirmative action is only a requirement for accomplishment of regulation accommodating the necessity for the minority, but without the implication that quota $30 \%$ has never been achieved because of the election system, which is unorganized in case of affirmative action principles. It, therefore, needs a new policy formulation relating to the election regulation, which can be implemented well and has implication on woman position in politic. In other words, the law politic of election is meant by the official line about election law in the country applied by regulation to make the election as one of ways to achieve the purpose of the country. 


\section{Conclusions}

1. In post-reformation period, the general election from 1999 to 2014 shows that the policy of Affirmative Action has not been accomplished quota $30 \%$ of female in parliament.

2. The politic policy of general election in the future must accomplish the policy of Affirmative Action with the quota $30 \%$ for female. Indonesia election system must prioritize several main factors relating to its system, political parties policy and approaches of political culture in Indonesia.

\section{References}

1. A. Najemi. jpkm, 30, 1, (2015)

2. B. Shanti, JP, 19, (2001)

3. E. Warasih, Pranata hukum Sebuah Telaah Sosialogis,: Suyandara Utama, Semarang

4. M. Gaffar, Janedjri. Politik Hukum Pemilu, (Konstitusi Pers, Jakarta, 2012)

5. Mahfud MD, Moh., Politik Hukum di Indonesia (Rajawali Pers, Jakarta, 2009)

6. Muladi, Demokratisasi, Hak Asasi Manusia, dan Reformasi Hukum di Indonesia, (The Habibie Centre, Jakarta, 2002)

7. N. Shvedova, Perempuan di Parlemen: Bukan Sekedar Jumlah, Bukan Sekedar Hiasan, (Yayasan Jurnal Perempuan, Jakarta, 1999)

8. P. Wahjono, Indonesia Negara Berdasarkan Atas Hukum, (Jakarta: Ghalia Indonesia, 1986)

9. P. Wahjono, Menyelisik Proses terbentuknya Peraturan Perundang-undangan, Forum Keadilan, No 29 april 1991

10. S. Soekanto, Masalah Kedudukan dan Peranan Hukum Adat, (Academia Jakarta, 1997)

11. T. Triwulan Tutik, Konstitusi Hukum Tata Negara Indonesia Pasca Amandemen UUD 1945 (Kencana, Jakarta, 2015)

12. T. Mohamad Radhie, Pembaharuan dan Politik Hukum dalam Rangka Pembangunan Nasional, in Prisma magazine No. 6 year II December 1973 